\title{
ИСТОЧНИКОВЕДЕНИЕ
}

DOI: https://doi.org/10.15688/jvolsu4.2019.2.5

UDC 930.272

Submitted: 25.11 .2018

LBC 63.3

Accepted: 14.03 .2019

\section{DOCUMENTS OF THE RUSSIAN ARCHIVE OF JAN PIOTR SAPIEHA: FINDINGS OF 2013-2018}

\author{
Igor O. Tyumentsev \\ Volgograd Institute of Management, Branch of Russian Presidential Academy of National Economy \\ and Public Administration, Volgograd, Russian Federation
}

\section{Nataliya A. Tupikova}

Volgograd State University, Volgograd, Russian Federation

Nina E. Tyumentseva

Volgograd State University, Volgograd, Russian Federation

\begin{abstract}
Introduction. The authors analyze previously unknown forty documents from the Archive of Jan Sapieha of 1608-1611 discovered over the last five years. The authors apply the following Methods: Russian and Polish Archeography, Historical Source Studies, Paleography and Linguistic Source of Studies. The new materials significantly fill in the earlier revealed "gaps" in archival fund previously reconstructed on the basis of preserved and published data on the events of the Time of Troubles. The necessity of looking for new data is determined by the demand for further exploration of one of the most important periods in the history of Russia. Introduction of revealed new documents to the scientific discourse enables us to examine previously known events from new perspectives reflecting confrontation of different political forces, to correlate 2 the newly-appeared facts, to clear up the process of converting Russian population to Cossacks by means of $\vec{\sim}$ robbing the populace (zemshchina) on the territories under "Tushino Regime", to detail the circumstances of $\hat{f}$ the beginning of the first militia, systematize the information about the state of peasants and orders reigning in Cossack Regiments of Tushino forces as well as in governing bodies of local administration (office ल environment), to reveal the sources of popular unrests in occupied Moscow, to show social and class, family and household problems of Russian people on the lands occupied by outlanders. The research performed $\sum_{0}^{0}$ resulted in many-faceted characteristics of the documents that significantly extend the informative value of g the reconstructed archive giving new opportunities for scientific research of events of the Time of Troubles. I.O. Tyumentsev read, systematized the documents, gave description of documents from the perspective of Archeography and Source Studies. N.A. Tupikova read and interpreted the content of the texts as well as 总 translated from Polish and commented the documents. N.E. Tyumentseva read the documents translated from Latin and commented fragments written in Latin.

Key words: History of Russia, the Time of Troubles, Source Studies, Archeography, reconstruction of Russian Archive of Jan Sapieha.

Citation. Tyumentsev I.O., Tupikova N.A., Tyumentseva N.E. Documents of the Russian Archive of Jan Piotr Sapieha: Findings of 2013-2018. Vestnik Volgogradskogo gosudarstvennogo universiteta. Seriya 4, Istoriya. Regionovedenie. Mezhdunarodnye otnosheniya [Science Journal of Volgograd State University. History. Area Studies. International Relations], 2019, vol. 24, no. 2, pp. 44-54. (in Russian). DOI: https://doi.org/10.15688/ jvolsu4.2019.2.5
\end{abstract}




\title{
ДОКУМЕНТЫ РУССКОГО АРХИВА ЯНА САПЕГИ: НАХОДКИ 2013-2018 ГОДОВ
}

\author{
Игорь Олегович Тюменцев \\ Волгоградский институт управления - филиал Российской академии народного хозяйства \\ и государственной службы при Президенте Российской Федерации, г. Волгоград, Российская Федерация
}

\section{Наталия Алексеевна Тупикова}

Волгоградский государственный университет, г. Волгоград, Российская Федерация

\section{Нина Егоровна Тюменцева}

Волгоградский государственный университет, г. Волгоград, Российская Федерация

Аннотация. Введение. Авторы анализируют найденные за последние пять лет 40 не известных ранее документов русского архива Яна Сапеги 1608-1611 годов. Используются методы русской и польской археографии, исторического источниковедения, палеографии, лингвоисточниковедения. Публикуемые матеpиальl восполняют выявленные «лакуны» архивного фонда, реконструированного ранее на основе сохранившихся и опубликованных источников о событиях Смутного времени. Необходимость поиска новых сведений связана с насущной потребностью дальнейшего изучения одного из важнейших периодов в истории России. Вовлечение в научный оборот новонайденных документов позволяет выявить новые ракурсы известных событий, отражающих противостояние различных политических сил, соотнести открывшиеся факты, дополнить картину показачивания населения России за счет ограбления земщины на территориях, находившихся под «тушинским режимом», детализировать обстоятельства начала первого земского ополчения, систематизировать сведения о положении крестьян и порядках, царивших в казачьих полках тушинского воинства, а также в приказной среде местных администраций, определить истоки народных волнений в осажденной Москве, показать социально-сословные, семейные и бытовые проблемы русских людей на захваченных иноземцами землях. В результате проделанной работы дана многоаспектная характеристика документов, что существенно расширяет информативную ценность реконструированного архива, открывая новые возможности для научного исследования событий Смутного времени. И.О. Тюменцев выполнил систематизацию, прочтение, археографическое и источниковедческое описание документов, Н.А. Тупикова осуществила прочтение и уяснение содержания текстов, перевод с польского языка и лингвоисточниковедческое комментирование документов, Н.Е. Тюменцева дала прочтение, перевод и комментирование латиноязычных фрагментов.

Ключевые слова: история России, Смутное время, источниковедение, археография, реконструкция русского архива Яна Сапеги.

Цитирование. Тюменцев И. О., Тупикова Н. А., Тюменцева Н. Е. Документы русского архива Яна Сапеги: находки 2013-2018 годов // Вестник Волгоградского государственного университета. Серия 4, История. Регионоведение. Международные отношения. - 2019. - Т. 24, № 2. - C. 44-54. - DOI: https://doi.org/ 10.15688/jvolsu4.2019.2.5

Введение. Смута начала XVII столетия круто изменила ход истории стран Восточной Европы, прежде всего, русского народа. Изучение событий той поры является одной из актуальных задач современной науки, однако оно сильно затруднено из-за гибели архивных материалов во время пожаров и социальных потрясений. Обращение к поставленной проблеме сопряжено с необходимостью расширения и уточнения представлений об исторической, историографической, источниковедческой и лингводокументоведческой составляющих реконструируемого архива, о реальных фактологических сторонах данной специфики документов. Именно поэтому критический анализ немногих дошедших до нас архивных собраний имеет большое значение для дальнейших продвижений в осмыслении эпохи.

Материалы и анализ. Архив полковника, а затем гетмана Лжедмитрия II Яна Петра Са- 
пеги, согласно гипотезе польских и российских историков XVIII-XX вв., накапливался в походной канцелярии предводителя наемных солдат в течение трех лет пребывания войска в России - с лета 1608 г. по сентябрь 1611 года. После смерти Я. Сапеги 4 (14) сентября 1611 г. его солдаты вывезли документы вместе с телом своего гетмана и передали вдове. Затем, в течение XVII-XX вв., материалы архива были разделены и попали в различные коллекции в библиотеки и архивы России, Польши, Украины, Швеции. К настоящему времени установлено, что бумаги Я. Сапеги отложились среди материалов собраний Сапег (Рожанское, Красиловское), графов Браге (бывшее Березинское), Ходкевичей, Радзивиллов, Чарторыских, Оссолиньских, в коллекциях П.А. Муханова, С.В. Соловьева, Г.Д. Хилкова, Н.Н. Дубровского (см.: [6, с. 4 5]). Отдельные письма имеются в собраниях Соликамской приказной палаты, Чаловского и Пергаминовых или хранились до их гибели в библиотеках Залуцких, Бжостовского, Главного штаба. Основной массив документов Я. Сапеги до 1606 г. опубликован А. Прохазкой в «Архиве дома Сапег»; значительная часть архива 1608-1611 гг. известна также из различных российских и польских изданий (см.: $[6$, с. 5; 10; 11]). Отыскать письма Яна Сапеги в Киевском и Виленском собраниях Сапег не удалось.

С помощью дневника Яна Сапеги [3; 11], в котором содержатся многочисленные упоминания, а кроме того, цитаты из документов, нами был составлен и опубликован подробный каталог выявленных и не найденных документов гетмана «Русский архив Яна Сапеги 1608-1611 годов: опыт реконструкции и источниковедческого анализа» [5], открывший возможность дальнейшего целенаправленного разыскания материалов в библиотеках и архивах. В ходе подготовки первого издания «Русский архив Яна Сапеги 1608-1611 годов. Тексты, переводы, комментарии» [6] некоторые упоминаемые в каталоге бумаги были отысканы, что подтвердило правильность примененной методики. В 2012 г. состоялась публикация в систематизированном виде основного массива выявленных документов из русского архива «воровского» гетмана Яна Петра Сапеги 1608-1611 гг., существенно расши- ряющая известные сведения о московском походе иноземного войска [2].

За прошедшие шесть лет в Польше, Швеции и на Украине шведским филологом-архивистом Э. Лёфстранд и молодым российским историком С.В. Мирским были найдены новые, не учтенные в наших изданиях, сапежинские бумаги (ср.: [4 и 12; 13]). С.В. Мирскому удалось дополнить первый и четвертый разделы архива, отыскав неизвестные письма Лжедмитрия II и войсковые документы сапежинцев. Наиболее значительные находки совершила, разбирая материалы архива Смоленской приказной избы в Государственном архиве Швеции, Элизабет Лёфстранд. Исследовательница выявила и оцифровала около тридцати документов, которые существенно пополнили материалы третьего раздела анализируемого собрания письмами, отписками и челобитными жителей Замосковья и Поморья. В результате проделанной работы к 420 опубликованным документам прибавилось еще 40 и их общее число достигло 460. Если учесть, что только одно перехваченное сапежинцами почтовое отправление из Троице-Сергиева монастыря содержало около 500 писем, то становится понятно, что найденные материалы капля в море. Однако используемые вместе с записями «Дневника» Я. Сапеги они открывают более широкие перспективы исследований, нежели любая летопись, сказание, хроника или записки иностранцев.

Будучи систематизированными по разделам и фондам архива, выявленные 40 документов буквально «взламывают» прежнюю нумерацию опубликованных документов. Чтобы избежать этого, новонайденному источнику присваивается номер предыдущего документа с добавлением буквенных литер «а», «б» и т. д. и сохраняется таким образом имеющаяся нумерация. Именно поэтому все упоминаемые ниже бумаги снабжены буквенными литерами, и их место в ранее опубликованном 2-м томе архива Я. Сапеги легко найти.

Все материалы русского архива Яна Сапеги систематизированы нами по четырем основным разделам, внутри которых образованы «фонды».

Раздел № 1. Переписка с Лжедмитрием II, его окружением и центрами повстанческого движения состоит из семи 
фондов, в которых шестью документами пополнились только три.

В фонд 1.1. Переписка и договоры Я. Сапеги и его солдат с Лжедмитрием II вошли два документа, о существовании которых мы знали по составленной нами описи документов архива Я. Сапеги: № $38 \mathrm{a}$. 1609 г. августа 2 (12). - Письмо Лжедмитрия II Я.П. Сапеге о возросшей опасности со стороны изменников с приказанием выступать навстречу русским правительственным войскам // Отдел рукописей Львовской научной библиотеки Национальной академии наук Украины (ОР ЛНБ НАНУ). Ф. 103. № 149/Уb. № 62. Л. 158-158 об. Копия А. Прохазки № 39. 1609 г. августа 8 (18). - Письмо Лжедмитрия II Я.П. Сапеге о содержании иноземной пехоты и необходимости как можно скорее разгромить войска кн. М.В. Скопина-Шуйского, пока они не приблизились к Москве// Отдел рукописей Львовской научной библиотеки Национальной академии наук Украины (ОР ЛНБ НАНУ). Ф. 103. № 149/Уb. Копия А. Прохазки № 63. Л. 159. Документы содержат новые данные о походе «воровского» гетмана к Твери против правительственного войска на помощь А. 3боровскому.

Новонайденные документы относятся к жанру официальных писем, сходных с назначением указных грамот. Такая деловая корреспонденция, адресантом которой является Лжедмитрий II, составляет важную часть архивного фонда. Анализ польскоязычных текстов данной группы свидетельствует о сложившейся типовой структуре документов: в начальном протоколе используется интитуляция, подчеркивающая претензии самозванца на престол (Dymitr Iwanowicz z łaski Bożej car Moskiewski wszej Rusi dmitrowskie, ugleckie, grodeckie etc., etc., xsiąże i innych wielu państw $i$ hord tatarskich monarchiej Moskiewskiej podległych pan i dziedzic). В конечном протоколе обязательным являются пожелание здоровья, место, дата написания письма и подпись (Życzymy zatem wmci dobrego zdrowia od Pana Boga. Datum w obozie 12 aug[usta] 1609. Dymitr car). В обоих отысканных посланиях указан адресат, включающий указание на происхождение, должность лица, используются устойчивые фразы речевого этикета ([Zac]nie urodzonemu panu Jan[u Piot]rowi Sapiezie pułkowni[ku nas]zemu uprzejmie y wiernie nam miłemu). Основная часть текстов документов включает два обязательных элемента: мотивировочную и инициаторную части. Мотивировочная часть содержит указание на полученные ранее сведения или совершенные ранее действия (отправку предшествующего послания) и вводится клишированными выражениями («Mamy sprawę», «Pisaliśmy do wmci w liście naszym»). Инициаторная часть в письме № 38а представляет собой приказание совершить действия и вводится с помощью глагола волеизъявления «żądamy»; инициаторная часть документа № 39, в котором главным является выражение надежды на помощь со стороны Сапеги против правительственных войск (Chcielibyśmy radę od wmci mieć), начинается с просьбы о получении совета по поводу того, как поступить с требованиями иноземных солдат в сложившейся ситуации.

Фонд 1.6. Переписка с воеводами и жителями Великих Лук, Торопияа, Невеля $u$ Заволочья пополнился одним, но очень ценным документом, отражающим процесс показачивания населения России: № 95а. Конец 1608 года. - Челобитная князя И.Р. Шаховского Лжедмитрию II с просьбой разрешить произвести набор казаков и идти с ними на Новгород Великий // Stokholm. Riksarkivet. Skoklostersamlingen. Ryska briev (SRSRB). E 8610. PEA 46. В научной литературе при выдвижении гипотезы о показачивании и формировании вольных казачьих войск на территории России ссылаются на переславскую челобитную о наборе в казаки Федором Копниным (№ 227). Документ в составе архива Я. Сапеги существенно дополняет описание этого процесса. В нем зафиксировано, что новоявленные атаманы набирали свои станицы с санкции самозванца, брали в них боевых холопов, молодежь из податных и духовенства, вооружали и снабжали их за счет ограбления земщины и являлись с ними в войско самозванца.

Фонд 1.7. Переписка сапежинщев с командирами отрядов наемников, властями и жителями городов южной украины России и руководством первого земского ополчения пополнился тремя документами: № 98а. 1609 год. - Челобитная детей боярских и казаков Украиных городов ливенцев, ельчан, епи- 
фанцев, рящан, пронян, михайловцев, донковцев, соловлян и дедиловцев Лжедмитрию II о жаловании за три года верной службы // Stokholm. Riksarkivet. Skoklostersamlingen. Ryska briev (SRSRB). E 8610. PEA 331 (1-2); № 98б. - Челобитная казаков полка Лисовского П.О. и А.И. Вороновых Лжедмитрию II и о жаловании за трехлетнюю службу // SRSRB. E 8610. PEA 48.1-2; № 112a. 1611, янв. - февр. - Письмо Ф.К. Смердова-Плещеева кн. В.М. Рубцу-Мосальскому и П.З. Ляпунову о их неуважительном обращении к гетману, полковникам и рыцарству // SRSRB. E 8610. PEA 52. Уникальность этих документов заключается в том, что они содержат сведения о службах повстанцев со времени показачивания в ходе Елецкого и Северского восстаний 1606 года. Помимо этого в них существенно уточняются время и обстоятельства начала первого земского ополчения, о чем мы делали доклад на недавней конференции в Москве и опубликовали статью [8].

Новонайденные русскоязычные челобитные, включенные в фонды 1.6 и 1.7, с лингвоисточниковедческой точки зрения относятся к ярким примерам проявления индивидуального в деловой письменности начала XVII века. Они написаны хорошо читаемыми почерками: крупный четкий почерк выделяет документы PEA 48 (1-2), PEA 331 (1-2), неровный размытый в ряде мест, но достаточно ясно читаемый почерк представлен в PEA 46. Об оригинальности документов свидетельствуют разные начерки букв, отражающие осмысление пишущими графического и функционального назначения букв [9, c. 138-139]. Так, в PEA 331 (1-2) четко противопоставляется правописная традиция «ерь» и «ер»; в РЕА 46 и PЕА 48 различаются начерки гласных «ять», «ерь»; в РЕА 331 (1-2) и РЕА 48 выделяется особый начерк «ы». Отличаются в PEA 46 и PEA 48 начерки согласных «д》 и «В» и т. д. Отмечается выраженность (РЕА 48) либо не выраженность (PEA 46, PEA 331) в текстах московского аканья.

Документ, помещенный под № $112 \mathrm{a}$ (PEA 52), относится к группе писем, изложение которых отличается прямотой оценок адресатов послания. Текст написан четким почерком в принятой скорописной традиции.
Обращают на себя внимание краткие зачин и концовка с трафаретной деловой формулой с церковнославянским элементом «яз» («яз челом бью») и не часто используемое титулование (господам) («Господам князю Василю Михаиловичю да Прокофю Захаревичю Федор Плещеев челом бьет»). Основная часть напоминает частное письмо, однако тон послания свидетельствует о назидательно-резком изложении сути претензий, изобилует негативными характеристиками и уничижительными для адресатов сравнениями с использованием московского просторечия. Лингводокументоведческий анализ указанных документов не оставляет сомнений, что новонайденные бумаги - это подлинники.

Раздел № 2. Грамоты, письма, челобитные приверженцев царя В. Шуйского, перехваченные сапежинцами, расспросные речи пленных и перебежчиков о действиях правительственных сил также содержит семь фондов, из которых пятью письмами удалось пополнить только три фонда. Фонд 2.2. Письма москвичей, расспросные речи перебежчиков и тушинских лазутчиков о ситуации в столице пополнился одним документом: № 139а. 1609 г. 14 (24).03. Челобитная московских выходцев Я. Пешкова Я. Сапеге с просьбой отпустить их в Тушино к Лжедмитрию II // SRSRB. E 8610. PEA 58. Документ содержит дополнительные сведения о народных волнениях в осажденной тушинцами Москве в феврале - марте 1609 года.

В Фонде 2.3. Документы зашитников Трочие-Сергиева монастыря и расспросные речи пленников и перебежчиков появились три не известные ранее письма: № 164a. 1609 г. 29.03 (8.04). - Письмо царевны-инокини Ольги (Годуновой) из Троице-Сергиева монастыря в Москву бабушке Стефании Андреевне с вестями о себе и о положении осажденных // SRSRB. E 8610. PEA 34; № 172a. 1609 г. 29. 06 (9.07). - Письмо старицы Еуфимии зятю И.Ф. Богатырову из Троице-Сергиева монастыря в Москву с вестями о себе и близких с просьбой добиться жалования для внуков // SRSRB. E 8610. PEA 35, 45v; № 179a. 1609 г., нач. июля. - Письмо попа Хотькова монастыря Стефана из Троице-Сергиева монастыря в Москву на Троицкое подворье игумену Спасского монастыря на Сходне Кипре- 
яну с вестями о себе и близких // SRSRB. E 8610. PEA 33 r-v. Наибольший интерес представляет послание царевны-инокини Ольги (Ксении Борисовны Годуновой), которое текстуально и палеографически полностью совпадает с известным ранее от того же числа. Документы отличаются лишь адресатами, что позволяет уточнить родственные связи Годуновых с другими боярскими родами. Всем трем письмам посвящена наша статья, которая вышла в «Вестнике СПбГУ» [7].

Один из наиболее бедных документами Фонд 2.5. Отписки воевод, челобитные служилых людей из городов Литовской Украины, расспросные речи пленных и перебежчиков получил еще одно письмо: № 183a. 1608 г., ок. 28.07 (7.08). - Челобитная могилевских купцов Я. Сапеге с просьбой компенсировать их убытки за забранные у них деньги и лошадей // SRSRB. Е 8610. PEA 55. Эти купцы упоминаются в дневнике как пострадавшие от грабежа сапежинцев во время похода на Москву.

Письма, представленные среди новонайденных русскоязычных документов, отражают структуру и содержание неофициального общения - грамоток, то есть устную малограмотную речь не профессиональных писцов, выражающих неровным почерком без оглядки на нормы приказного и церковнославянского языков свои мысли. В зачинах и концовках грамоток просматриваются элементы стандартизации при использовании слов и выражений, «навеянных» книжностью, приказным слогом и принятым в светской среде речевым этикетом (А я тебе, своему г(осу)д(а)рю, мало пишу, а мно(г)о чело(м) бью. Да г(осу)д(а)р(е)мь мои(м) <..> по великому челобитию). В концовках обращает на себя внимание употребление свойственной для деловой письменности вплоть до XVIII в. конструкции инфинитив + Им. п. сущ. ж. $p$. на -а, которая была составной частью живого языка и использовалась для формулирования просьбы пишущего $[1$, с. 50,52$]$, часто в стандартном окончании, завершающем послание, перед указанием на местонахождение и имя адресата (Дати грамотка на Мо(с)кве на Троецко(м) по(д)ворье Спа(с)каму игумену с(а) Сходни Кипреяну Макарьевичю). Это показывает усвоение адресантами исторически сложившихся фор- мул эпистолярного письма. Основная часть текста грамоток облекается в форму разговорной речи, что проявляется в переключении с одной темы на другую, не всегда мотивированную предшествующим контекстом, в употреблении экспрессивных фраз и обращений, в отражении стихии простонародного непринужденно-бытового языка.

Не ограничиваясь простым изложением дел, авторы грамоток иногда прибегают к эмоциональному повествованию с выразительными, окрашенными личным чувством изображениями событий, фактов, моментов, особенно их волновавших. Это, помимо невысокого уровня грамотности и знания норм церковной и приказной традиций, объясняет в ряде случаев написание документов почерком, чтение которого более затруднительно в сравнении с иными. В грамотках, адресованных близким людям, в особенности написанных от имени женского лица, получает отражение та среда общения, к которой принадлежит автор письма. Здесь встречаются свойственные как книжному литературному языку выражения, так и колоритные речевые элементы народной речи, «разговорности», фольклорные обращения (Къ (госуда)р(ы)не моеі светъ бабушке; до(ч) чело(м) бье(т); Буди, г(осу)д(а)р(ы)ня, здарова на многие лета; А я тобе г(осу)д(а)р(ы)не свету много чело(м) бью).

В разделе № 3. Письма, отписки и челобитные из Замосковья и Поморья, получившем самое значительное пополнение, выделено тринадцать фондов.

В Фонде 3.1. Переписка с владимирскими воеводами появилась крестьянская челобитная, подобных которой ранее в этой группе документов практически не было. Она свидетельствует о том, что положение крестьян в захваченном сапежинцами Владимирском уезде ничем не отличалась от других уездов Замосковья: № 190а. 1608 г. п. 1 (11).11. - Челобитная крестьян Польской и Кривандинской волостей Владимирского уезда Лжедмитрию II с просьбой защитить от загонщиков и непомерных налогов // SRSRB. E 8610. PEA 141.

Относительно малочисленный Фонд 3.2. Отписки, челобитные и росписи из Вологды и Галицкого уезда также теперь включают аналогичную челобитную, рисующую жуткое ограбление местных крестьян: № 204a. 
1608 г., ноябрь. - Челобитная крестьян Заболоцкой волости Б. Иванова и В. Васильева Я. Сапеге с просьбой освободить их от поставок пива и хлеба // SRSRB. E 8610. PEA 60.

В Фонде 3.4. Челобитные и отписки служильх людей и крестьян Московского уезда появились сразу четыре новых документа, отразивших ситуацию в монастырских селах Чудова и Троице-Сергиева монастыря. Особенно интересна челобитная крестьян троицкой вохонской волости, которая открывает ряд обращений к самозванцу крестьян этого бывшего дворцового села, боровшихся за возращение своего прежнего статуса: № 214a. 1608 г., конец сент. - Челобитная крестьян Замосковной половины Запольские волости Чудова монастыря сел Заполное и Осташково Лжедмитрию II о готовности присягнуть ему на верность // SRSRB. E 8610. PEA 42; № 217a. 1609 г., нач. апр. - Челобитная села Боркова Никитской церкви попа Василия Лжедмитрию II с просьбой дать ему к Пасхе корову // SRSRB. E 8610. PEA 332; № 219a. Осень 1608 года. - Челобитная Лжедмитрию II и Я.П. Сапеге крестьян Вохонской волости Московского уезда с просьбой разрешить покупать хлеб во Владимире на Клязьме // SRSRB. E 8610. PEA 53; № 221а. 1608 г., осень. - Челобитная старост подмосковного дворцового села Петровского с приселком Богородицким К. Кородавов троецкого села Муромцева М. Фролова Лжедмитрию II с просьбой не брать у них хлеб, оставшийся после разорения московскими загонщиками и тушинскими казаками // SRSRB. E 8610. PEA 49.

Фонд 3.6. Челобитные и отписки жителей Переяславля-Залесского и Переяславского уезда оказался самым обширным из фондов анализируемого раздела. Это связано с близостью названных уездов к местонахождению сапежинских лагерей у Троице-Сергиева монастыря Переяславского уезда. Фонд пополнился восемью новыми челобитными, в которых упоминаются многие ранее известные нам лица и проясняется их судьба. В нашем распоряжении оказались по 3-5 челобитных из дворцовых и монастырских сел, которые позволяют выяснить, как тушинские власти реагировали на отчаянные мольбы крестьян и посадских о защите их жизней, семей, имущества от насилий и грабежей: № 231a. 1608 г., ок. 27.12 (1609 г. 6.01). - Челобитная посадских людей Переславля Залесского Я. Сапеге с просьбой оставить у них приставом пана X. Конвинского и освободить от непосильных выплат за всякие кормы // SRSRB. E 8610. PEA 54 1-2; № 231б. 1608 г., кон. Челобитная посадских - плотников из Переславля Залесского Лжедмитрию II с просьбой издать указ о выделении переславским посадом денег на содержание плотникам, работающим «для царского дела» // SRSRB. E 8610. PEA 43; № 238а. 1608 г., кон. - Челобитная попа Юрия Покровской церкви Александровой слободы Лжедмитрию II с просьбой защитить его от обвинений попа Никифора // E 8610. PEA 38; № 246a. 1608 г., дек. - Челобитная попа церкви Пресвятые Богородицы Закубежской волости Н. Васильева Лжедмитрию II с просьбой разрешить служить в церкви и защитить оставшееся церковное имущество от грабежей и поборов // SRSRB. E 8610. PEA 41. 1-2; № 249a. 1608 г., кон. - Челобитная игумена Покрова Пресвятые богородицы Андреяновой пустыни Варлаама и Успения Пресвятые богородицы попа Андрея Лжедмитрию II с просьбой дать распоряжение Суздальскому архиепископу Галактиону дать все необходимое для возобновления церковной службы в разоренной обители // SRSRB. E 8610. PEA 39; № 249б. 1608 г., дек. - Челобитная игумена Покрова Пресвятые богородицы Андреяновой пустыни Варлаама Лжедмитрию II с просьбой запретить властям дворцовой Окружной волости собирать корм и налоги с принадлежащей монастырю Богородицкой слободки // SRSRB. E 8610. PEA 40. 1-2; № 253a. 1608 г., 26.12 (5.01). - Челобитная Лжедмитрию II крестьян посопного села Жердеива Переславского уезда с просьбой освободить их от сбора обыскных денег из-за крайнего разорения от загонных людей // SRSRB. E 8610. PEA 44; № 258a. 1608 г., дек. - Челобитная крестьян дворцового с. Рождествено Переславского уезда Лжедмитрию II c просьбой освободить их от непосильных поборов из-за их крайнего разорения // SRSRB. Е 8610. PEA 47.

Относительно малочисленный Фонд 3.7. Челобитные и отписки служилых людей и духовенства из Пошехонья приобрел один 
документ: № 263a. 1608 г., ноябрь. - Челобитная сына боярского пошехонца И.В. Исакова Лжедмитрию II с просьбой не брать кормов с его деревни, разоренной изменниками // SRSRB. E 8610. PEA 50. Это одна из немногих дошедших до нас в составе архива челобитных городового сына боярского, которая свидетельствует, что имения служилых людей также подвергались невиданному грабежу, а их владельцы были вынуждены погибать на «воровской» службе.

Фонд 3.9. Письма наемников, отписки воевод, челобитные ростовских служилых людей, посадских и крестьян пополнился тремя документами: № 275a 1609 г. п. 16 (26).01 .Челобитная иноков Ионы (Фролова) и казначея Гурия (Митрофанова) Ростовского Борисоглебского монастыря Лжедмитрию II с мольбой защитить братию, слуг и крестьян от гибели и полного разорения // SRSRB. E 8610. PEA 37. 1-4; № 276a. - Фрагмент описания лошадей в царском (?) табуне // SRSRB. Е 8610. PEA 36; № 282. 1609 г., лето. - Челобитная казака государевой станицы В. Петрова Я. Сапеге с просьбой защитить его от правежа денег // SRSRB. E 8610. PEA 56.1-2. Наибольший интерес представляет последняя из указанных челобитных, которая содержит уникальные сведения о порядках, царивших в казачьих полках тушинского воинства, образованных из показачившегося населения России.

В Фонде 3.11. Письма, отписки и челобитные наемников, воевод и жителей из Углича и Угличского уезда появилась подорожная, которая была выдана известным по другим документам доверенным лицом Я. Сапеги паном Я. Очковским князю И.Ф. Мышецкому: № 313а. 1608 г., 27.11 (7.12). - Подорожная пана Я. Очковского князю И. Ф. Мышецкому из Углича до Троице-Сергиева монастыря // SRSRB. E 8610. PEA 1. 1-2.

Фонд 3.12. Отписки и челобитные воевод и жителей из Юрьева Польского, в котором преобладали отписки местного воеводы, пополнился челобитной местного духовенства: № 320а. 1608 г., ноябрь. - Челобитная посадских священников Юрьева Польского Я. Сапеге с просьбой собирать с них налоги по старине // SRSRB. E 8610. PEA 59.1-2. Документ позволяет взглянуть на события той поры под иным углом зрения, нежели это нашло отражение в записках местного воеводы.

Весьма любопытна появившаяся в Фонде 3.13. Отписки и челобитные воевод и жителей Ярославля новая челобитная: № 345 a. 1608 г., ноябрь. - Челобитная ярославского подьячего Ф. Никитина Лжедмитрию II с просьбой перевести его в Романов для вершения судных и четвертных дел и назначения жалования // SRSRB. E 8610. PEA 45.1-2-v. Источник знакомит нас с порядками, царившими в приказной среде местных администраций Замосковных и Поморских уездов России.

Вышеприведенные русскоязычные документы имеют все характерные черты, присущие жанру челобитья. Документы включают три основные клаузулы: начальная и заключительная части текста - устойчивые формулы, употреблявшиеся в деловой речи того времени; основной текст демонстрирует свободу выражения мысли, что определяет большую пространность или краткость изложения обстоятельств дела и просьбы. Четко просматриваются элементы стандартизации, что сопряжено с использованием устойчивых формул приказного делопроизводства. Выражены также приметы народно-разговорной речи, носителями которой являются челобитчики.

Подорожная относится к немногочисленной группе такого рода документов в составе архива и представляет собой официальную бумагу, удостоверяющую право на беспрепятственный и обеспеченный всем необходимым проезд указанного лица от Углича до Троицы «с санми и с хомуты и з проводники везде не издержав ни часу». Написанный по-русски текст содержит трафаретное указание на собственноручную подпись поручителя скрепу, выраженную по-польски (reką swa), и подпись польского подданного.

Всешесть новых документов, пополнивших раздел № 4. Переписка с Сигизмундом III, С. Жолкевским, А. Гонсевским и Семибоярщиной, частными лицами в Речи Посполитой и войсковые документы, относятся к фонду 4.1. Переписка с королем Сигизмундом III: № 384a. 1610 г. 20 (30).11. Инструкция, данная королевским послам Л. Вайеру, С. Витовскому и Б. Копцю, отправленным для переговоров с «рыцарством» полка Я.П. Сапеги // Stokholm Riksarkivet 


\section{ИСТОЧНИКОВЕДЕНИЕ}

Skoklostersammlingen. Polska brev (SRSPB). Е 8597; № 3846. 1610 г. 20 (30).11. - Инструкция послам сапежинцев п. Казимирскому и п. Ивановскому, отправленным для переговоров в королевский лагерь под Смоленском // SRSPB. E 8597; № 384в. - Сведения послам для свершения успешного дел наших // SRSPB. Е 8597; № 386a. 1611 г. 14 (24).01. - Второй ответ короля Сигизмунда III послам сапежинцев // SRSPB. Е 8597; № 389а. 1611 г., февр. Письмо польского короля Сигизмунда III caпежинцам с просьбой не уходить из России // SRSPB. E 8597; № 3896. 1611 г. 4 (14).03. Инструкция солдат полка Я.П. Сапеги пану Яниковскому на переговоры с королевскими властями под Смоленском // SRSPB. Е 8597. Они позволяют внести важные уточнения в переговоры сапежинцев с королем Сигизмундом III Вазой о возвращении солдат на службу, времени и обстоятельствах зарождения Первого земского ополчения.

Послания Сигизмунда III - копии с подлинных бумаг. Как и все документы, вышедшие из королевской канцелярии, они являют собой образцы словесного искусства того времени на польском языке. Новонайденные документы это официальные ответы послам сапежинцев. Однако тексты отличаются по форме изложения: в письме с просьбой не уходить из России использована «мы-форма» и интенции говорящего, эмоционально ориентированные на некоторую доверительность обращения, увещевающий, убеждающий характер просьбы; второй ответ короля дан от «третьего лица», подчеркивающего статус и высокое положение королевской особы, написан в холодном и категоричном тоне, с ярко выраженной направленностью апеллировать к ценностям, которые связаны с авторитетом власти и незыблемыми постулатами в иерархии польского общества, с пониманием того, к чему следует относиться с надлежащим уважением.

Инструкции составлены по правилам делового письма, имеют начальную и конечную части, содержание которых определяет соблюдение этикета при оглашении требований со стороны королевской особы или от имени войска: в начале текстов - изъявление королевской милости / нижайших служб и верного подданства его милости королю, в конце - выражение благосклонности и подобающей щедрости монарха / ожидания вознаграждения от короля со стороны войска. В инструкции послам сапежинцев, данной войском, содержится также напоминание о сроках возвращения с ответом от короля. Основная часть текстов включает перечень пунктов, требующих оглашения.

Результаты. Представленный обзор новых документов русского архива Я. Сапеги 1608-1611 гг. свидетельствует о богатстве содержащейся в них информации, не в полной мере отраженной в предпринятых нами изданиях. Восполнить данный пробел можно будет во втором издании реконструируемого собрания. Прошедшие шесть лет показали, что возможности в изучении архива далеко не исчерпаны, часто утраченные документы погибших собраний всплывают в поздних копиях, а уже опубликованные материалы и вновь найденные источники требуют дополнительного рассмотрения на основе многоаспектного анализа. «Рукописи не горят!».

\section{СПИСОК ЛИТЕРАТУРЫ}

1. Владимирова, Л. А. Употребление конструкции отдать ся грамотка в письменности XVII в. / Л. А. Владимирова // История русского языка и лингвистическое источниковедение. - М. : Наука, 1987. - С. 50-52.

2. Выписка из дневника московского похода Яна Сапеги 1608-1611 гг. // Сын отечества и Северный архив. - 1838. - Т. 1, № 1/2. - Отд. 3. - С. 29-64.

3. Дневник Яна Петра Сапеги (1608-1611 гг.) / сост. И. О. Тюменцев, М. Яницкий, Н. А. Тупикова, А. Б. Плотников. - М. ; Варшава : Древлехранилище, 2012. - 456 с. - (Памятники истории Восточной Европы. Источники XV-XVII вв. ; т. 9).

4. Российский государственный архив древних актов в Москве (РГАДА). - Ф. 1204. Шведские микрофильмы (новые поступления). - Рул. 133. - Ч. 2.

5. Русский архив Яна Сапеги 1608-1611 годов: опыт реконструкции и источниковедческого анализа / авт. коллектив: И. О. Тюменцев (рук.) [и др.] ; под ред. проф. О. В. Иншакова. - Волгоград : Изд-во ВолГУ, 2005. - 340 c.

6. Русский архив Яна Сапеги 1608-1611 годов. Тексты, переводы, комментарии / под ред. И. О. Тюменцева. - Волгоград : Изд-во Волгогр. фил. РАНХиГС, 2012. -688 с.

7. Тюменцев, И. О. Новые письма и челобитные Смутного времени из Троице-Сергиева мона- 
стыря и его вотчин / И. О. Тюменцев, Н. А. Тупикова // Вестник Санкт-Петербургского университета. История. - 2018. - Т. 63, вып. 3. - С. 935-948.

8. Тюменцев, И. О. Сапежинцы и зарождение Первого земского ополчения в Смугное время в России по материалам русского архива Яна Сапеги / И. О. Тюменцев // Три даты трагического пятидесятилетия Европы (1598-1618-1648). Россия и Запад в годы Смуты, религиозных конфликтов и Тридцатилетней войны. - М. : ИВИ РАН, 2018. - С. 95-105.

9. Филиппова, И. С. Об употреблении букв ъ и $b$ в московских рукописях XVII века / И. С. Филиппова // Исследования по истории русского языка и письменности. - М. : Наука, 1966. - С. 122-139.

10. Флоря, Б. Н. Два письма начала XVII в. из Троице-Сергиева монастыря / Б. Н. Флоря // История русского языка : Исследования и тексты : сб. ст. / отв. ред. В. Г. Демьянов, В. Ф. Дубровин. - М. : Наука, 1982. - С. 319-325.

11. Sapieha, J. P. Dziennik / J. P. Sapieha // Hirschberg A. Polska a Moskwa w pierwszej połowie weku XVII. - Lwów, 1901. - T. 1. -S. 167-324.

12. Stokholm. Riksarkivet. Skoklostersamlingen. Polska brev (SRSPB). - E 8597; E 8604.

13. Stokholm. Riksarkivet. Skoklostersamlingen.Ryska briev(SRSRB). -E 8610 (1 и 2).

\section{REFERENCES}

1. Vladimirova L.A. Upotreblenie konstruktsii «otdat sya gramotka» v pismennosti XVII v. [Using the Combination "otdat sya gramotka" in the Writing of the $17^{\text {th }}$ Century]. Istoriya russkogo yazyka $i$ lingvisticheskoe istochnikovedenie [History of the Russian Language and Linguistic Source Study]. Moscow, Nauka Publ., 1987, pp. 50-52.

2. Vypiska iz dnevnika moskovskogo pokhoda Yana Sapegi 1608-1611 gg [Extract from the Diary of the Moscow Campaign of Jan Sapieha 1608-1611]. Syn otechestva i Severnyy arkhiv [Son of the Fatherland and the North Archive], 1838, vol. 1, no. 1/2, Sec. 3, pp. 29-64.

3. Tyumentsev I.O., Yanitskiy M., Tupikova N.A., Plotnikov A.B., eds. Dnevnik Yana Petra Sapegi (1608-1611 gg.) [Diary of Jan Peter Sapieha (1608-1611)]. Moscow, Warsaw, Drevlekhranilishche Publ., 2012. 456 p. (Pamyatniki istorii Vostochnoy Evropy. Istochniki XV-XVII vv.; t. 9 [Documents of the History of Eastern Europe. Sources of the $15^{\text {th }}-$ $17^{\text {th }}$ Centuries; vol. 9]).

4. Rossiyskiy gosudarstvennyy arkhiv drevnikh aktov v Moskve (RGADA) [Russian State Archive of Ancient Acts in Moscow], F. 1204, Swedish Microfilms (New Acquisitions), Rul. 133, Part 2.
5. Tyumentsev I.O., et al. Russkiy arkhiv Yana Sapegi 1608-1611 godov: opyt rekonstruktsii i istochnikovedcheskogo analiza [The Russian Archive of Jan Sapieha of 1608-1611: Experience in Reconstruction and Source Study Analysis]. Volgograd, Izd-vo VolGU, 2005. 340 p.

6. Tyumentsev I.O., ed. Russkiy arkhiv Yana Sapegi 1608-1611 godov. Teksty, perevody, kommentarii [The Russian Archive of Jan Sapieha for 1608-1611. Texts, Translations, Comments]. Volgograd, Izd-vo Volgogradskogo filiala RANKhiGS, 2012. $688 \mathrm{p}$.

7. Tyumentsev I.O., Tupikova N.A. Novye pisma i chelobitnye Smutnogo vremeni iz Troitse-Sergieva monastyrya i ego votchin [New Letters and Petitions of the Time of Troubles from the Trinity-Sergius Monastery and Its Patrimonies]. Vestnik SanktPeterburgskogo universiteta. Istoriya [Vestnik of Saint Petersburg University. History], 2018, vol. 63, iss. 3, pp. 935-948.

8. Tyumentsev I.O. Sapezhintsy i zarozhdenie Pervogo zemskogo opolcheniya v Smutnoe vremya v Rossii po materialam russkogo arkhiva Yana Sapegi [Sapezhintsy and the Birth of the First Zemstvo Militia in the Time of Troubles in Russia according to Materials from the Russian Archive of Jan Sapieha]. Tri daty tragicheskogo pyatidesyatiletiya Evropy (1598-1618-1648). Rossiya i Zapad v gody Smuty, religioznykh konfliktovi Tridtsatiletney voyny [Three Dates for the Tragic 50th Anniversary of Europe (15981618-1648). Russia and the West during the Time of Troubles, Religious Conflicts and the Thirty Years' War]. Moscow, IVI RAN Publ., 2018, pp. 95-105.

9. Filippova I.S. Ob upotreblenii bukv $b$ i $b$ v moskovskikh rukopisyakh XVII veka [On the Use of the Letters $b$ and $b$ in Moscow Manuscripts of the 17th Century]. Issledovaniya po istorii russkogo yazyka i pismennosti [Studies on the History of the Russian Language and Writing]. Moscow, Nauka Publ., 1966, pp. 122-139.

10. Florya B.N. Dva pisma nachala XVII v. iz Troitse-Sergieva monastyrya [Two Letters of the Early 17th Century from the Trinity-Sergius Monastery]. Istoriya russkogo yazyka: Issledovaniya i teksty: sb. st. [History of the Russian Language: Studies and Texts. Collection of Articles]. Moscow, Nauka Publ., 1982, pp. 319-325.

11. Sapieha J.P. Dziennik. Hirschberg A. Polska a Moskwa w pierwszej polowie wieku XVII. Lviv, 1901, vol. 1, pp. 167-324.

12. Stokholm. Riksarkivet. Skoklostersamlingen. Polska brev (SRSPB). E 8597; E 8604.

13. Stokholm. Riksarkivet. Skoklostersamlingen. Ryska briev (SRSRB). E 8610 (1 and 2). 


\section{Information about the Authors}

Igor O. Tyumentsev, Doctor of Sciences (History), Professor, Director, Volgograd Institute of Management, Branch of Russian Presidential Academy of National Economy and Public Administration, Gagarina St., 8, 400131 Volgograd, Russian Federation, tijumencev@mail.ru, https://orcid.org/0000-00028762-9308

Nataliya A. Tupikova, Doctor of Sciences (Philology), Professor, Department of Russian Philology and Journalism, Volgograd State University, Prosp. Universitetsky, 100, 400062 Volgograd, Russian Federation,na_tupikova@volsu.ru, tupikova195@mail.ru, https://orcid.org/0000-0002-9217-8441

Nina E. Tyumentseva, Candidate of Sciences (History), Associate Professor, Department of German and Romanic Philology, Volgograd State University, Prosp. Universitetsky, 100, 400062 Volgograd, Russian Federation, tyumenceva.nina@mail.ru, tyumenceva.nina@volsu.ru, https://orcid.org/0000-00020545-658X

\section{Информация об авторах}

Игорь Олегович Тюменцев, доктор исторических наук, профессор, директор, Волгоградский институт управления - филиал Российской академии народного хозяйства и государственной службы при Президенте Российской Федерации, ул. Гагарина, 8, 400131 г. Волгоград, Российская Федерация, tijumencev@mail.ru, https://orcid.org/0000-0002-8762-9308

Наталия Алексеевна Тупикова, доктор филологических наук, профессор кафедры русской филологии и журналистики, Волгоградский государственный университет, просп. Университетский, 100, 400062 г. Волгоград, Российская Федерация, na_tupikova@volsu.ru, tupikova195@mail.ru, https://orcid.org/0000-0002-9217-8441

Нина Егоровна Тюменцева, кандидат исторических наук, доцент кафедры германской и романской филологии, Волгоградский государственный университет, просп. Университетский, 100, 400062 г. Волгоград, Российская Федерация, tyumenceva.nina@mail.ru, tyumenceva.nina@volsu.ru, https://orcid.org/ 0000-0002-0545-658X 